\title{
Beyond the species pool: Modification of species dispersal, establishment and assembly by habitat restoration
}

\author{
RH: Restoration modify dispersal and establishment
}

\author{
Péter Török ${ }^{1 *}$, Aveliina Helm², Kathrin Kiehl ${ }^{3}$, Elise Buisson ${ }^{4}$, Orsolya Valkó ${ }^{5}$ \\ ${ }^{1}$ MTA-DE Lendület Functional and Restoration Ecology Research Group, Hungary \\ ${ }^{2}$ Institute of Ecology and Earth Sciences, University of Tartu, Estonia \\ ${ }^{3}$ Vegetation Ecology and Botany, Osnabrück University of Applied Sciences, Germany \\ ${ }^{4}$ IMBE, Université d'Avignon et des Pays de Vaucluse, CNRS, IRD, Aix Marseille \\ Université, Avignon, France \\ ${ }^{5}$ MTA-DE Biodiversity and Ecosystem Services Research Group, Hungary \\ *Corresponding Author: molinia@gmail.com
}

Author Contributions: PT developed the first version of the theoretical background; all authors contributed to the manuscript writing and revised the manuscript draft.

\begin{abstract}
Species dispersal, establishment and assembly are crucial stages of the life history of plants, and clear understanding of the governing forces and rules that shape species composition in a particular community is vital for successful ecological restoration. In our paper we focus on five aspects of seed dispersal and plant establishment, which should be considered during habitat restoration actions. In the first two sections we discuss the success of spontaneous dispersal and establishment on restoration based either on spatial dispersal or local seed banks. In the third section we assess the possibilities of species introduction and assisted dispersal. In the fourth section we introduce some possibilities for the improvement of establishment success of spontaneously dispersed or introduced species. Finally, we highlight issues influencing long-term persistence and sustainability of restored habitats, related to the alteration of management type and intensity, climate change and spread of non-native species. With the present paper we introduce the special issue entitled 'Seed dispersal and soils seed banks - Promising sources for ecological restoration' containing 15 papers by 62 authors from ten countries arranged into the abovementioned five topics.
\end{abstract}

Keywords: dispersal; species assembly; ecological theory; seed bank; spontaneous succession; technical reclamation

This article has been accepted for publication and undergone full peer review but has not been through the copyediting, typesetting, pagination and proofreading process, which may lead to differences between this version and the Version of Record. Please cite this article as doi: 10.1111/rec.12825 


\section{Implications for practice}

- The potential of spatial and temporal seed dispersal needs to be evaluated before site selection and restoration planning.

- Knowledge on seed bank, seed rain and landscape-scale dispersal helps to identify the most proper, well-timed and cost-effective restoration measures.

- Creation of small-scale environmental heterogeneity and favorable conditions for species establishment is crucial for maximizing restoration success.

- Suppression of unwanted species via prevention of immigration and depletion of their seed banks is crucial.

- It is vital to plan restoration at the landscape-scale for ensuring the exchange of seeds and pollen between habitats, to apply the most suitable post-restoration management, and to ensure that established communities are resilient to climate change. 


\section{Introduction}

Species dispersal and establishment are crucial stages in the life history of plant species, and clear understanding of governing forces and rules that shape species composition and assembly in a particular community is fundamental for a successful ecological restoration. Species dispersal and establishment success are influenced by a set of factors, including the composition of species pool, habitat conditions determining environmental filtering and ecosystem dynamics (Kraft \& Ackerley 2014). The species pool represents a set of possibly colonizing species that are 'filtered' to the final community by regional processes (e.g. dispersal), environmental and biotic factors (=filters) and interactions or internal dynamics (White \& Jentsch 2004). These filters must be considered as dynamic because communities are dynamic themselves. Additionally, different filters depend on each other via feedback loops (Belyea 2004; Fattorini \& Halle 2004). When determining the processes that filter species to communities, one can apply either top down (from species pool to community) or bottom up (from community to species pool) approach (Temperton \& Hobbs 2004). Some authors proposed to divide the total species pool in two: the external species pool including species occurring in the landscape, and the internal species pool with species already present on site, e.g. in the seed bank, bud bank, egg bank or still alive after the disturbance (Fattorini \& Halle 2004). This second pool is part of what White \& Jentsch (2004) called disturbance legacy.

A simplified scheme of the interaction of species pools, filters and restoration measures is introduced in Figure 1. Only a fraction of the total species pool is able to reach a particular site (i.e. available species), and species arrival is governed by spontaneous dispersal processes (Prach \& Pyšek 2001). Spontaneous species dispersal has a spatial component, 
which means that dispersal in space is facilitated by abiotic and biotic vectors. While the spontaneous spatial dispersal has attracted quite high attention in the literature, the temporal component of dispersal, e.g. the formation of persistent seed and bud banks, but also temporal dynamics of spatial dispersal, have gained so far much less attention (but see Pausas et al. 2018). The available species pool (i.e. species able to arrive at a particular site) is generally further filtered by abiotic conditions of the respective habitat (i.e. abiotic filtering) and later by the respective species assembly at the site (i.e. biotic filtering). While abiotic conditions filter species from the species pool which are able to establish in a respective habitat, biotic filtering sorts out those species that are not able to assemble in a respective community. Due to successional changes, however, the species composition of an established community is not constant over time (Hobbs et al. 2007). Fluctuations and internal community dynamics strongly influence the actual species composition in a site (Fig. 1).

Applied to restoration, this scheme makes it possible to draw some generalities from various projects and provide guidelines (Temperton \& Hobbs 2004). It implies that for each restoration project, one must consider i) the regional processes determining the composition of species pool and species dispersal, ii) the actual and predicted environmental conditions and habitat characteristics favoring the target community species and iii) biotic interactions (Menninger \& Palmer 2006). In this context it is crucial to know that different filters can be important at different restoration stages (Hobbs \& Norton 2004). Identifying the key filters allows the determination of the steps needed to be taken during the restoration process (Hobbs \& Norton 2004) and to decide if active restoration measures are needed or if passive restoration by unassisted succession may be sufficient to reach restoration goals (Prach et al. 2007). In the last few decades there has been an increasing demand to link ecological theory with the practice of restoration, and it was argued that the implication of theories in 
restoration increase its applicability and success (Prach \& Hobbs 2008; Török \& Helm 2017). With the current special feature and editorial focus on five topics of restoration clearly linked to the above introduced filtering scheme (Fig. 1). The ultimate goal of habitat restoration is to reach a species composition and community functioning similar to a predefined idealized target community (van Andel \& Aronson 2012; Helm et al. 2015).

This means that during active restoration we aim at modifying the species composition of a particular site by directing compositional changes or development of a species assembly towards a desirable targeted direction (Kiehl et al. 2010; Tischew et al. 2014). For a costeffective planning and implementation of target species transfer, as well as for ensuring longterm viability of the restored community, it is vital to know in which magnitude a restoration action can be based on spontaneous spatial dispersal and local seed banks. Thus, spontaneous succession or assisted regeneration are increasingly promoted (Prach \& Hobbs 2008). Spontaneous succession is either based on local propagule banks or on spatial dispersal of target species. These topics are introduced in the following sections 1 and 2 . In section 3 , we focus on species introduction, with which it is possible to overcome dispersal limitation. This is generally done by sowing of seed mixtures or plant material transfer (Kiehl et al. 2010; Török et al. 2011). For an effective establishment of species from the habitat-specific species pool (Helm et al. 2015) it is often necessary to modify abiotic and biotic habitat conditions in degraded landscapes (section 4). Finally, the long-term persistence of restored communities is strongly linked to the long-term modification and direction of internal community dynamics. Long-term sustainability can be strongly influenced by climate change or by the spread of invasive non-native species and the suitability of management measures for reaching restoration targets (section 5). 
This special issue entitled 'Seed dispersal and soils seed banks - Promising sources for ecological restoration' contains 15 papers by 62 authors from ten countries arranged into the above mentioned five topics. The special issue was initiated during the SER Europe Conference 2016 on 'Best practice in Restoration' (Freising, Germany, 22-26 August, 2016). The contributing author teams were mostly invited from the special session 'Soil seed banks and seed dispersal - Promising sources for restoration' organized by the guest editors. The special issue is developed with the collaboration and support of the European chapter of the Society for Ecological Restoration (Box 1).

\section{(1) Success of spontaneous dispersal and colonization}

Species spontaneous colonizations and extinctions are fundamental components of community dynamics. In ecological restoration, spontaneous dispersal of propagules is a highly relevant process that has to be carefully incorporated in restoration planning (Török \& Helm 2017). Patterns of unassisted dispersal of target and non-target species and the potential of target communities to benefit from seed rain determine which restoration measures are needed and how restoration has to be carried out. When target species are expected to arrive fast, restoration can largely focus on re-creating necessary physical conditions and on ensuring the establishment success (Prach \& Pyšek 2001; Valkó et al. 2017; Aradottir \& Halldorsson 2018, this issue). When spontaneous colonization of target species is unlikely to occur, or can result in arrival of unwanted species, species introductions and assisted dispersal are needed (see section 3 and Kiehl et al. 2010).

However, the scientific knowledge about the positive and negative effects of spontaneous dispersal is far from complete (Arruda et al. 2018, this issue). Recovery of vegetation via spontaneous dispersal is a complicated process and depends on multitude of factors such as 
composition of the species pool, landscape structure and connectivity, land-use history, dispersal ability of species, availability and behavior of dispersal vectors as well as on aspects related to seed production and predation (Marteinsdóttir 2014; Prach et al. 2015; Johanidesová et al. 2015; Solbreck \& Knape 2017; Arruda et al. 2018, this issue; Schwab et al. 2018, this issue). The capacity to incorporate all the aspects in practical restoration is hindered both by the lack of standardization in approaches and methods, as well as by the lack of basic knowledge of the processes. Based on a systematic review of grassland literature, Arruda et al. (2018, this issue) point out that there are significant knowledge gaps in seed rain research depending on grassland types and concerning the role of native animals as seed dispersers, pre-dispersal and post-dispersal seed predation and the effect of seed rain on arrival of non-native species. Aavik \& Helm (2018, this issue) additionally emphasize that not only dispersal of seeds needs to be considered, but the drivers of gene flow in general: successful restoration also needs to result in the recovery of genetic diversity, which is dependent both on seed and pollen flow in the landscape, as well as on population size. Thus, in order to ensure that restored ecosystems will harbor viable, genetically diverse populations and diverse communities, restoration planning should specifically aim for the recovery of landscape-scale spontaneous dispersal of target species (Török \& Helm 2017; Aavik \& Helm 2018, this issue). Aavik \& Helm (2018, this issue) list a number of genetic and ecological tools that allow assess landscape-scale dispersal for selecting appropriate restoration methods and monitor restoration success. They also propose recommendations for restoration planners and practitioners to consider while aiming to restore self-sustainable ecosystems with high species- and gene-level biodiversity.

The knowledge of factors influencing spontaneous dispersal in watercourses is even scarcer than in terrestrial habitats (Bourgeois et al. 2016). Schwab et al. (2018, this issue) studied the 
effects of the surrounding vegetation and the local species pool on seed dispersal from the Danube to a newly connected watercourse in the Danube floodplain and between different habitat types within the restored floodplain. They found that connecting restoration sites with upstream donor habitats enhanced restoration success but also pointed out that upstream seed sources of potentially invasive non-target species have to be reduced.

Integral component of spontaneous colonization is the establishment success following seed dispersal (section 4). Aradóttir \& Halldorsson (2018, this issue) showed in severely degraded and erosion-prone landscapes in Iceland that colonization of woody species has been both seed and microsite limited; thus, both aspects need to be addressed for successful restoration. In their study, creation of colonization and establishment nuclei via planting "woodland islets" served as a tool to overcome both seed and microsite limitation.

In general, knowledge-based approaches to re-connect habitats and to improve conditions for target seed dispersal will promote enhance success (see also other studies of this issue). Each restoration project, however, has its specific conditions and often large efforts are necessary prior restoration for incorporating spontaneous dispersal effects and maximizing restoration success, as well as after restoration for monitoring ecological consequences of implemented measures (Watson et al. 2017; Arruda et al. 2018, this issue).

\section{(2) Effectiveness and role of seed bank in restoration}

The quality and quantity of the soil seed bank of restoration sites is one of the most important prerequisites which determines the required actions and the rate and type of species introductions. In their meta-analysis, Bossuyt \& Honnay (2008) found that in most grassland 
and forest communities, target species with persistent seed bank are too scarce to effectively support spontaneous recovery. This is especially true, because most of the rare species, and also several characteristic matrix species generally lack persistent seed banks in these communities (Kiss et al. 2016; Klaus et al. 2018, this issue; Godefroid et al. 2018, this issue; Török et al. 2018, this issue). In wetlands, heathlands and habitats with frequent and unpredictable disturbances, regeneration from the seed bank is more important and thus persistent seed banks can support the spontaneous recovery of these habitats better than in grasslands or forests (Bossuyt \& Honnay 2008, Kiss et al. 2018, this issue). In general, the role of seed bank in recovery decreases with increasing community stability. Thus, in stable communities, due to the lack of disturbances creating gaps for germination and establishment most species do not have persistent seed banks (Bossuyt \& Honnay 2008; Schwab \& Kiehl 2017). But also in ancient grassland habitats regularly disturbed by fire, such as old-growth campo rupestre grasslands, seed bank was found to be insufficient for community recovery after severe anthropogenic disturbance (Le Stradic et al. 2018, this issue). Obviously the bud bank is more important in regularly burnt old-growth grasslands than the seed bank (Fidelis et al. 2014; Pausas et al. 2018) and resprouting seems to be the major way of plant regeneration (see also Kiss et al. 2018, this issue).

In general, sites with a shorter history of degradation can be restored with higher success based on the local seed bank (Bekker et al. 1997). This finding should be considered in restoration prioritization: if resources for restoration are limited, site managers should select less severely degraded sites for spontaneous recovery or assisted restoration. Given the low contribution of soil seed banks to vegetation recovery, enabling the spatial component of seed dispersal is crucial in restoration projects (see Török et al. 2018, this issue). Landscape-scale extent and spatial configuration of reference grasslands should be evaluated and sites where 
spatial dispersal of target species is more promising and where unwanted invasive species are absent should be prioritized for spontaneous recovery.

In general, the soil seed bank of degraded sites mainly consists of undesired species (Török et al. 2012; Hess et al. 2018, this issue; Klaus et al. 2018, this issue; Török et al. 2018, this issue). Thus, information about the composition of the seed bank can inform site managers about the most important future threats, such as the encroachment of weeds and invasive species. With this knowledge, they can also plan the necessary restoration actions. If the seed bank contains mainly undesired species, it is important not to allow its activation, i.e. drastic site preparation by soil disturbance without additional introduction of target species should be avoided (see Valkó et al. 2016; Klaus et al. 2018, this issue). If the seed bank is largely infested by invasive species, only its complete removal can prevent future invasion. Hess et al. (2018, this issue) provided a novel approach for eradicating the seed bank of undesired species by microwave heating of soils. Even though the method is currently being fine-tuned for larger-scale field application, it seems to be a promising and innovative approach to fight against invasive species without pesticide application.

Finally, knowledge on soil seed banks also supports the monitoring of restoration success and helps us estimate the resilience of the restored communities. Török et al. (2018, this issue) evaluated the success of spontaneous recovery of sandy old-fields in a chronosequence study and showed that the development of seed banks is also a proper indicator of restoration success. Seed bank informs us about community resilience, which is especially important faced with changing climate as shown by Kiss et al. (2018, this issue). This study highlighted that in stable habitats, characterized by predictable and less severe disturbance, such as nonfire-prone temperate grasslands, climate-induced changes in disturbance regimes cannot be 
buffered by soil seed bank in the future. They showed that climate-driven changes in disturbance regimes can lead to directional and irreversible changes in species composition and density of soil seed bank, especially in currently stable ecosystems.

\section{(3) Species introduction and assisted dispersal}

As mentioned above, the restoration of grassland ecosystems is often limited by seed availability because of depleted seed banks and limited dispersal of diaspores due to a lack of dispersal vectors, especially for long-distance dispersal (Walker et al. 2004; Buisson et al. 2006a; Klaus et al. 2018, this issue; Török et al. 2018, this issue). Also in other plant communities of ancient cultural landscapes, e.g. in arable ecosystems, populations of rare and threatened target species are often fragmented due to changed land-use techniques (e.g. herbicide application, changed crop rotation, seed cleaning of crops in arable ecosystems). Nowadays, most rare and threatened arable weed species are not able to disperse over longer distances (Mayer \& Albrecht 2008, Lang et al. 2018, this issue).

Therefore, active species introduction is necessary, when target species are absent on restoration sites in fragmented landscapes and are not able to reach them by natural dispersal (Kiehl 2010, Tischew et al. 2014). Suitable restoration measures include e.g. the transfer of freshly harvested seed-containing hay or raked material, seeding of site-specific seed mixtures (Hedberg \& Kotowski 2010; Kiehl et al. 2010; Kiehl et al. 2014). The transfer of diaspore-rich topsoil can also be used to introduce target species (Scotton et al. 2012; Jaunatre et al. 2014), but it strongly damages the donor site and should mainly be used, when donor sites are destroyed anyway e.g. by construction works. Although many studies have shown a successful restoration of ecosystems by species transfer, information about practical 
details of species introduction techniques and about mechanisms of target species establishment is still missing for different types of plant communities.

Buisson et al. (2018, this issue) evaluated the effects of the transfer ratio and the timing of topsoil-transfer on the establishment of typical dry grassland species in Mediterranean grasslands. Although the seed bank contained more species in summer than in spring in their study, topsoil transfer in spring was more successful for the establishment of target species concerning both species richness and species composition compared to topsoil translocation in autumn. The different transfer ratios of 1:1 and 1:3 (donor:receptor site) had no significant effect on vegetation development, which indicates that a ratio of 1:3 was sufficient for dry grassland restoration in Southern France. Long-term establishment of target communities was, however, mainly affected by the underlying seed bank at the receptor site, which contained competitive non-target species hampering restoration success (see also Jaunatre et al. 2014).

Lang et al. (2018, this issue) introduced arable weed species, which had become rare due to herbicide application in conventional farming, to organic farms where the probability of population persistence is higher under suitable management. They showed that it was possible to establish new populations by seeding, but only two out of three species (Consolida regalis, Legousia speculum-veneris) were able to build up a persistent soil seed bank at the restoration sites. In contrast, the available seed bank of Lithospermum arvense was rapidly depleted in unfavorable years (e.g. by mice feeding). Cultivation techniques led to a short distance dispersal of seeds over $16 \mathrm{~m}$ within fields in three years indicating that species may disperse further in the future especially when sown strips of target species are set up rectangular to the direction of cultivation is carried out, instead along the field margins. 
Wagner et al. (2018, this issue) investigated not only the establishment of introduced target species but also the seed bank dynamics in soils of grasslands restored by sowing of low and high-diversity seed mixtures. Sowing of species-rich grass-forb mixtures was reflected in a faster build-up of sown forbs in the seed bank and a faster decline of non-target forbs in comparison to species-poor mixtures containing only grasses. Interestingly, seed bank composition and dynamics were more affected by the composition of the seed mixtures than by cultivation techniques prior to sowing (deep vs. shallow cultivation).

\section{(4) Improvement of establishment success}

Following their arrival in a given community, species need to germinate, survive, grow and reproduce. Only species with the physiological capacities to establish in particular environmental conditions can do so. One main restoration action is therefore to manipulate and re-establish adequate abiotic conditions before introducing species or leaving spontaneous succession to work (Fig. 1). This may include manipulation of soil texture and nutrient concentrations (Hobbs \& Norton 2004; Heneghan et al. 2008; Melnik et al. 2018, this issue). In general, species diversity increases with habitat heterogeneity, which provides more niches for different species. Thus, ecological restoration often aims at creating structurally complex habitats and safe sites (del Moral et al. 2007; Aradóttir \& Halldorsson 2018, this issue) by modifying the abiotic and the biotic components of ecosystems: microtopography, substrate heterogeneity, biocrust and ecosystem engineers, such as ant mounds, thin moss, tussock grasses and dwarf-shrubs can play a major role in creating this heterogeneity (Whisenant 2002; Larkin et al. 2006; Menninger \& Palmer 2006; Aradóttir \& Halldorsson 2018, this issue). Indeed, Melnik et al. (2018, this issue) found that variability in micro- 
topography and substrate can support the expression of a wide range of species from the seed bank. They showed that site managers can make use of this method even at the operational scale. Aradóttir \& Halldorsson (2018, this issue) showed that, in severely degraded and erosion-prone landscapes in Iceland, colonization of woody species is microsite limited, and the creation of establishment nuclei via planting "woodland islets" is useful.

Species also interact with each other: these interactions can be negative (competition) or positive (facilitation), and both of them can considerably influence restoration success (Fig. 1). Plant species compete for limited resources, such as water, nutrients, light, whereas animal species compete for prey and space. Plant and animal communities also interact. While everyone agrees that primary producers have the primacy in controlling the structuring of communities, predator-prey interactions also play an important role. Dense stands of exotic or ruderal species can reduce or enable native target species to establish (Buisson et al. 2006b; D’Antonio \& Chambers 2006; Buisson et al. 2008; Buisson et al. 2018, this issue). Grazing is widely studied to restore open landscapes (e.g. Fisher et al. 1996; Opperman \& Merenlender 2000; Yates et al. 2000; Kiehl \& Pfadenhauer 2007) as it can limit competition, favor some species and introduce new species. Eichberg \& Donath (2018, this issue) studied the effects of simulated trampling by artificial sheep hooves on germination and seedling recruitment of plant species from dry sandy grasslands and of ruderals in a laboratory experiment. They showed that trampling pressed seeds into the upper soil layers and strongly promoted seedling emergence due to positive effects on microclimate. Not only target species but also ruderal species profited from trampling which means that in practical conservation and restoration of sandy grasslands appropriate grazing management is necessary to reduce the abundance of non-target species and to promote target species (see also Stroh et al. 2002). 
In the past 20 years, positive interactions between plants have been studied in detail (e.g. Callaway \& Walker 1997; Brooker et al. 2008) and have been applied to restoration (e.g. Gómez-Aparicio et al. 2004; Padilla \& Pugnaire 2006; Aradottír \& Halldorsson 2018, this issue). At the same time, there has been a growing interest in the linkage between belowground and above-ground biota because it influences community and ecosystem processes and properties (Wardle et al. 2004). To conclude, both negative and positive interactions must be taken into account in ecological restoration in order to improve restoration efforts (Menninger \& Palmer 2006; Halpern et al. 2007; Wagner et al. 2018, this issue).

\section{(5) Long-term persistence, sustainability and management}

Natural fluctuations and internal community dynamics strongly influence species establishment and assembly in natural ecosystems (Fig. 1). Both processes are strongly linked to the degradation of the species composition and functioning of ecosystems directly driven by altered intensity of management and climate change as well as by the spread of invasive species (Nelson et al. 2006).

Changes in management intensity i.e. intensification or cessation of former use can shift the species composition and ecosystem functioning in an undesired direction causing species loss. Management intensity changes were identified as the most crucial drivers of species loss in grasslands and other open habitat types over the Palaearctic (Török \& Dengler 2018, Carboni et al. 2015, Valkó et al. 2018). In most cases decreased management intensity will cause an increase in abundance and number of potentially dominant competitors of the subjected grassland community. During restoration planning, post-restoration management should be carefully selected because cessation or improper management can strongly threaten 
restoration success (Kelemen et al. 2014; Eichberg \& Donath 2018, this issue). Successful management of restored sites creates favorable light conditions, ensures the presence of gaps needed for the regeneration of target species and provides control of potentially dominant native and non-native non-target species (Tischew et al. 2014).

Climate change has become an emerging threat both to original and restored ecosytems (Harris et al. 2006), and together with the alteration of spatial and temporal patterns in precipitation and temperature, it also increases the chance of weather extremities. Climate change can induce community shifts i.e. by changing global and regional patterns of species distributions (Thuiller et al. 2005), by affecting population sizes and the timing of reproduction (Nelson et al. 2006) and by the facilitation of the spread of pests and biological invasions (Walther et al. 2009). The magnitude in which climate change affects ecosystems is highly variable in respect to the habitat type, and is often masked by other drivers including land-use and management changes. Impacts of global changes can be mitigated by ecological restoration via creation of resilient communities of native plant species with as high evolutionary potential as possible, as well as via fostering the landscape-scale movement of seeds and pollen in order to build up high habitat-specific species and gene-level diversity (Aavik \& Helm 2018, this issue). 


\section{Acknowledgements}

The Guest Editors are thankful to all of the Authors of the Special Issue, for the Editor in Chief Stephen Murphy, and Managing Editor Valter Amaral for their help in various stages of the process and the journal Restoration Ecology and Wiley Publisher making this special issue possible. We thank Johannes Kollmann, Julia-Maria Hermann and the organizing team of the SER Europe conference 2016, which made our special session possible. Special thanks for Jonathan Mitchley who provided help in revising SER Europe box-text. The support of NKFIH K 119225 grant (PT), NKFI KH 126476 (OV) and the Bolyai János Research Scholarship of the Hungarian Academy of Sciences (OV) is greatly acknowledged. AH acknowledges the support of the Estonian Ministry of Education and Research (IUT 20-29) and the European Union through the European Regional Development Fund (Centre of Excellence EcolChange). EB acknowledges the support of CNRS PICS 2018-2020 [RESIGRASS].

\section{Literature Cited}

Aavik T, Helm A (2018) Restoration of plant species and genetic diversity depends on landscape-scale dispersal. Restoration Ecology this issue

Aradóttir AL, Halldorsson G (2018) Colonization of woodland species during restoration propagule or safe site limitation? Restoration Ecology this issue

Arruda AJ, Buisson E, Poschlod P, Silveira FA (2018) How have we studied seed rain in grasslands and what do we need to improve for better restoration? Restoration Ecology this issue

Bekker RM, Verweij GL, Smith REN, Reine R, Bakker JP, Schneider S (1997) Soil seed banks in European grasslands: Does land use affect regeneration perspectives? Journal of Applied Ecology 34:1293-1310

Belyea LR (2004) Beyond ecological filters: feedback networks in the assembly and restoration of community structure. Pages 115-131 In: Temperton VM, Hobbs RJ, Nuttle T, Halle S (eds) Assembly Rules and Restoration Ecology: Bridging the Gap Between Theory and Practice. Island Press, Washington, D.C.

Bossuyt B, Honnay O (2008) Can the seed bank be used for ecological restoration? An overview of seed bank characteristics in European communities. Journal of Vegetation Science 19:875-884

Bourgeois B, González E, Vanasse A, Aubin I, Poulin M (2016) Spatial processes structuring riparian plant communities in agroecosystems: implications for restoration. Ecological Applications 26:2103-2115

Brooker RW, Maestre FT, Callaway RM, Lortie CL, Cavieres L, Kunstler G, Liancourt P, Tielbörger K, Travis JMJ, Anthelme F, Armas C, Coll L, Corcket E, Delzon S, Forey E, Kikvidze Z, Olofsson J, Pugnaire F, Quiroz CL, Saccone P, Schiffers K, Seifan M, Touzard B, Michalet R (2008) Facilitation in plant communities: the past, the present and the future. Journal of Ecology 96:18-34 
Buisson E, Jaunatre R, Römermann C, Bulot A, Dutoit T (2018) Species transfer via topsoil translocation: lessons from two large Mediterranean restoration projects. Restoration Ecology this issue

Buisson E, Anderson S, Holl KD, Corcket E, Hayes GF, Peteers A, Dutoit T (2008) Reintroducing native perennial bunchgrass Nassella pulchra to degraded California coastal prairies. Applied Vegetation Science 11:195-204

Buisson E, Dutoit T, Torre FC, Römermann C, Poschlod P (2006a) The implications of seed rain and seed bank patterns for plant succession at the edges of abandoned fields in Mediterranean landscapes. Agriculture, Ecosystems \& Environment 115:6-14

Buisson E, Holl KD, Anderson S, Corcket E, Hayes GF, Peteers A, Dutoit T (2006b) Using grazing, topsoil removal, and plant neighbor removal to restore degraded California coastal prairies. Restoration Ecology 14:569-577

Callaway RM, Walker LR (1997) Competition and facilitation: a synthetic approach to interactions in plant communities. Ecology 78:1958-1965

Carboni M, Dengler J, Mantilla-Contreras J, Venn S, Török P (2015) Conservation value, management and restoration of Europe's semi-natural open landscapes. Hacquetia 14:517

del Moral R, Walker LR, Bakker JP (2007) Insights gained from succession for the restoration of landscape structure and function. Pages 19-44 In: Walker LB, Walker J, Hobbs RJ (eds) Linking restoration and ecological succession. Springer, New York

Eichberg C, Donath TW (2018) Sheep trampling on surface-lying seeds improves seedling recruitment in open sand ecosystems. Restoration Ecology this issue

Fattorini M, Halle S (2004) The dynamic environmental filter model: how do filtering effects change in assembling communities after disturbance? Pages 96-114 In: Temperton VM, Hobbs RJ, Nuttle T, Halle S (eds) Assembly rules and restoration ecology: Bridging the gap between theory and practice. Island Press, Washington, D.C.

Fidelis A, Appezzato-da-Glória B, Pillar VD, Pfadenhauer J (2014) Does disturbance affect bud bank size and belowground structures diversity in Brazilian subtropical grasslands? Flora 209:110-116

Fischer SF, Poschlod P, Beinlich B (1996) Experimental studies on the dispersal of plants and animals on sheep in calcareous grasslands. Journal of Applied Ecology 33:1206-1222

Godefroid S, Le Pajolec S, Hechelski M, Van Rossum F (2018) Can we rely on the soil seed bank for restoring xeric sandy calcareous grasslands? Restoration Ecology this issue

Gómez-Aparicio L, Zamora R, Gómez JM, Hódar JA, Castro J, Baraza E (2004) Applying plant facilitation to forest restoration: a meta-analysis of the use of shrubs as nurse plants. Ecological Applications 14:1128-1138

Halpern BS, Silliman BR, Olden JD, Bruno JP, Bertness MD (2007) Incorporating positive interactions in aquatic restoration and conservation. Frontiers in Ecology and the Environment 5:153-160

Harris JA, Hobbs RJ, Higgs E, Aronson J (2006) Ecological restoration and global climate change. Restoration Ecology 14:170-176

Hedberg P, Kotowski W (2010) New nature by sowing? The current state of species introduction in grassland restoration, and the road ahead. Journal for Nature Conservation 18: 304-308 
Helm A, Zobel M, Moles AT, Szava-Kovats R, Pärtel M (2015) Characteristic and derived diversity: implementing the species pool concept to quantify conservation condition of habitats. Diversity and Distributions 21(6):711-721

Heneghan L, Miller SP, Baer S, Callaham MA Jr, Montgomery J, Pavao-Zuckerman M, Rhoades CC, Richardson S (2008) Integrating soil ecological knowledge into restoration management. Restoration Ecology 16(4):608-617

Hess M, De Wilde M, Yavercovski N, Willm L, Mesléard F, Buisson E (2018) Microwave soil heating reduces seedling emergence of a wide range of species including invasives. Restoration Ecology this issue

Hobbs RJ, Norton DA (2004) Ecological filters, thresholds and gradients in resistance to ecosystem reassembly. Pages 72-95 In: Temperton VM, Hobbs RJ, Nuttle T, Halle S (eds) Assembly rules and restoration ecology: Bridging the gap between theory and practice. Island Press, Washington, D.C.

Hobbs R, Walker LR, Walker J (2007) Integrating restoration and succession. Pages 168-179 In: Walker LR, Walker J, Hobbs R (eds) Linking restoration and ecological succession. Springer, New York

Jaunatre R, Buisson E, Coiffait-Gombault C, Bulot A, Dutoit T (2014) Restoring species-rich Mediterranean dry grassland in France using different species-transfer methods. Pages 162-182 In: Kiehl K, Kirmer A, Shaw N, Tischew S (eds) Guidelines for native seed production and grassland restoration. Cambridge Scholars Publishing, Newcastle upon Tyne, UK

Johanidesová E, Fajmon K, Jongepierová I, Prach K (2014) Spontaneous colonization of restored dry grasslands by target species: restoration proceeds beyond sowing regional seed mixtures. Grass and Forage Science 70:631-638

Kelemen A, Török P, Valkó O, Deák B, Miglécz T, Tóth K, Ölvedi T, Tóthmérész B (2014) Sustaining recovered grasslands is not likely without proper management: vegetation changes after cessation of mowing. Biodiversity and Conservation 23:741-751

Kiehl K (2010) Plant species introduction in ecological restoration - possibilities and limitations. Basic and Applied Ecology 11:281-284.

Kiehl K, Kirmer A, Shaw N, Tischew S (eds) (2014) Guidelines for native seed production and grassland restoration. Cambridge Scholars Publishing, Newcastle upon Tyne, UK

Kiehl K, Kirmer A, Donath T, Rasran L, Hölzel N (2010) Species introduction in restoration projects - evaluation of different techniques for the establishment of semi-natural grasslands in Central and Northwestern Europe. Basic and Applied Ecology 11:285299

Kiehl K, Pfadenhauer J (2007) Establishment and persistence of target species in newly created calcareous grasslands on former arable fields. Plant Ecology 189:31-48

Kiss R, Tóthmérész B, Valkó O, Török P (2016) Seed bank research in central-European grasslands - an overview. Pages 1-33 In: Murphy J (ed) Seed banks: types, roles and research. Nova Scientific Publishers, New York

Kiss R, Deák B, Török P, Tóthmérész B, Valkó O (2018) Grassland seed bank and community resilience in a changing climate. Restoration Ecology this issue 
Klaus VH, Hoever, CJ, Fischer M, Hamer U, Kleinebecker T, Mertens D, Shäfer D, Prati D, Hölzel N (2018) Contribution of the soil seed bank to the restoration of temperate grasslands by mechanical sward disturbance. Restoration Ecology this issue

Kraft NJ, Ackerley DD (2014) Assembly of plant communities. Pages 67-88 In: Monson RK (ed) Ecology and the environment. Springer, New York

Lang M, Kollmann J, Prestele J, Wiesinger K, Albrecht H (2018) Reintroduction of rare arable plants on organic farms: Seed production, seed dispersal and soil seed bank three years after sowing. Restoration Ecology this issue

Larkin D, Vivian-Smith G, Zedler JB (2006) Topographic heterogeneity theory and ecological restoration. Pages 142-164 In: Falk DA, Palmer MA, Zedler JB (eds) Foundations of restoration ecology. Washington D.C., USA

Le Stradic S, Fernandes GW, Buisson E (2018) No recovery of campo rupestre grasslands after gravel extraction: implications for conservation and restoration. Restoration Ecology this issue

Marteinsdóttir B (2014) Seed rain and seed bank reveal that seed limitation strongly influences plant community assembly in grasslands. PloS ONE 9: e103352

Mayer F, Albrecht H (2008) Dispersal strategies: Are they responsible for species success in arable ecosystems? Pages 257-275 In: Schröder JPP, Munch JC (eds) Perspectives for agroecosystem management. Elsevier, Amsterdam

Melnik K, Landhäusser SM, Devito K (2018) Role of microtopography in the expression of soil propagule banks on reclamation sites. Restoration Ecology this issue

Menninger HL, Palmer MA (2006) Restoring ecological communities: from theory to practice. Pages 88-112 In: Falk DA, Palmer MA, Zedler JB (eds) Foundations of restoration ecology. Washington D.C., USA

Nelson GC, Bennett E, Berhe AA, Cassman K, DeFries R, Dietz T, Dobermann A, Dobson A, Janetos A, Levy M, Marco D, Nakicenovic N, O’Neill B, Norgaard R, Petschel-Held G, Ojima D, Pingali P, Watson R, Zurek M (2006) Anthropogenic drivers of ecosystem change: An overview. Ecology and Society 11:29

Opperman JJ, Merenlender AM (2000) Deer herbivory as an ecological constraint to restoration of degraded riparian corridors. Restoration Ecology 8:41-47

Padilla FM, Pugnaire FI (2006) The role of nurse plants in the restoration of degraded environments. Frontiers in Ecology and the Environment 4:196-202

Pausas JG, Lamont BB, Paula S, Appezzato-da-Glória B, Fidelis A (2018) Unearthing belowground bud banks in fire-prone ecosystems. New Phytologist 217:1435-1448

Prach K, Pyšek P (2001) Using spontaneous succession for restoration of human-disturbed habitats: Experience from Central Europe. Ecological Engineering 17:55-62

Prach K, Marrs R, Pyšek P, van Diggelen R (2007) Manipulation of succession. Pages 121149 In: Walker LR, Walker J, Hobbs R (eds) Linking restoration and ecological succession. Springer, New York

Prach K, Hobbs RJ (2008) Spontaneous succession versus technical reclamation in the restoration of disturbed sites. Restoration Ecology 16:363-366

Prach K, Fajmon K, Jongepierová I, Řehounková K (2015) Landscape context in colonization of restored dry grasslands by target species. Applied Vegetation Science 18:181-189 
Schwab A, Kiehl K (2017) Analysis of soil seed bank patterns in an oxbow system of a disconnected floodplain. Ecological Engineering 100:46-55

Schwab A, Stammel B, Kiehl K (2018) Seed dispersal via a new watercourse in a reconnected floodplain: differences in species groups and seasonality. Restoration Ecology this issue

Scotton M, Kirmer A, Krautzer B ed. (2012) Practical handbook for seed harvest and ecological restoration of species-rich grasslands. Padua, Italy: Cleup.

Solbreck C, Knape J (2017) Seed production and predation in a changing climate: new roles for resource and seed predator feedback? Ecology 98:2301-2311

Stroh M, Storm C, Zehm A, Schwabe A (2002) Restorative grazing as a tool for directed succession with diaspore inoculation: the model of sand ecosystems. Phytocoenologia 32:595-625

Temperton V, Hobbs RJ (2004) The search for ecological assembly rules and its relevance to restoration ecology. Pages 34-54 In: Temperton VM, Hobbs RJ, Nuttle T, Halle S (eds) Assembly rules and restoration ecology: Bridging the gap between theory and practice. Island Press, Washington, D.C.

Thuiller W, Lavorel S, Araújo MB, Sykes MT, Prentice IC (2005) Climate change threats to plant diversity in Europe. Proceedings of the National Academy of Sciences 102:82458250

Tischew S, Kirmer A, Kiehl K, Shaw N (2014) Planning and implementation of restoration projects using native seed and plant material. Pages 286-300 In: Kiehl K, Kirmer A, Shaw N, Tischew S (eds) Guidelines for native seed production and grassland restoration. Cambridge Scholars Publishing, Newcastle upon Tyne, UK

Török P, Kelemen A, Valkó O, Miglécz T, Tóth K, Tóth E, Sonkoly J, Kiss R, Csecserits A, Rédei T, Deák B, Szücs P, Varga N, Tóthmérész B. (2018) Succession in soil seed banks and implications for restoration of calcareous sand grasslands. Restoration Ecology (this issue)

Török P, Dengler J (2018) Palaearctic grasslands in transition: overarching patterns and future prospects. Pages 15-26 In: Squires VR, Dengler J, Feng H, Limin H (eds) Grasslands of the world: diversity, management and conservation. CRC Press, Boca Raton, US

Török P, Helm A (2017) Ecological theory provides strong support for habitat restoration. Biological Conservation 206:85-91

Török P, Miglécz T, Valkó O, Kelemen A, Deák B, Lengyel S, Tóthmérész B (2012) Recovery of native grass biodiversity by sowing on former croplands: is weed suppression a feasible goal for grassland restoration? Journal for Nature Conservation 20:41-48

Török P, Vida E, Deák B, Lengyel S, Tóthmérész B (2011) Grassland restoration on former croplands in Europe: An assessment of applicability of techniques and costs. Biodiversity and Conservation 20:2311-2332

Valkó O, Venn S, Zmihoski M, Biurrun I, Labadessa R, Loos J (2018) The challenge of abandonment for the sustainable management of Palaearctic natural and semi-natural grasslands. Hacquetia 17:5-16 
Valkó O, Deák B, Török P, Kelemen A, Miglécz T, Tóthmérész B (2017) Filling up the gaps - Passive restoration does work on linear landscape scars. Ecological Engineering 102:501-508.

Valkó O, Deák B, Török P, Kirmer A, Tishew S, Kelemen A, Tóth K, Miglécz T, Radócz S, Sonkoly J, Tóth E, Kiss R, Kapocsi I, Tóthmérész B. (2016) High-diversity sowing in establishment gaps: a promising new tool for enhancing grassland biodiversity. Tuexenia 36:359-378

van Andel J, Aronson J (2012) Getting started. Pages 3-8 In: van Andel J, Aronson J (eds) Restoration ecology - the new frontier. Wiley-Blackwell, Chichester

Wagner M, Walker KJ, Pywell RF (2018) Seed bank dynamics in restored grassland following the sowing of high- and low-diversity seed mixtures. Restoration Ecology this issue

Walker KJ, Stevens PA, Stevens DP, Mountford JO, Manchester SJ, Pywell RF (2004) The restoration and re-creation of species-rich lowland grassland on land formerly managed for intensive agriculture in the UK. Biological Conservation 119:1-18

Walther G-R, Roques A, Hulme PE, Sykes MT, Pyšek P, Kühn I, Zobel M, Bacher S, BottaDukát Z, Bugmann H, Czúcz B, Dauber J, Hickler T, Jarošík V, Kenis M, Klotz S, Minchin D, Moora M, Nentwig W, Ott J, Panov VE, Reineking B, Robinet C, Semenchenko V, Solarz W, Thuiller W, Vilà M, Vohland K, Settele J. (2009) Alien species in a warmer world: Risks and opportunities. Trends in Ecology and Evolution 24:686-693

Wardle DA, Bardgett RD, Klironomos JN, Setälä H, van der Putten WH, Wall DH (2004) Ecological linkages between aboveground and belowground biota. Science 304:16291633

Watson DM, Doerr VAJ, Banks SC, Driscoll DA, Van Der Ree R, Doerr ED, Sunnucks P (2017) Monitoring ecological consequences of efforts to restore landscape-scale connectivity. Biological Conservation 206:201-209

Whisenant SG (2002) Terrestrial ecosystems. Pages 83-105 In: Perrow MR, Davy AJ (eds) Handbook of Restoration Ecology. Vol. 1. Restoration in practice. Cambridge University Press, Cambridge, UK; New York

White PS, Jentsch A (2004) Disturbance, succession and community assembly in terrestrial plant communities. Pages 342-366 In: Assembly Rules and Restoration Ecology: Bridging the Gap Between Theory and Practice. Temperton VM, Hobbs RJ, Nuttle T, Halle S (eds), Washington, D.C.

Yates CJ, Norton DA, Hobbs RJ (2000) Grazing effects on plant cover, soil and microclimate in fragmented woodlands in south-western Australia: Implications for restoration. Austral Ecology 25:36-47 


\section{Ecological process Restoration action}
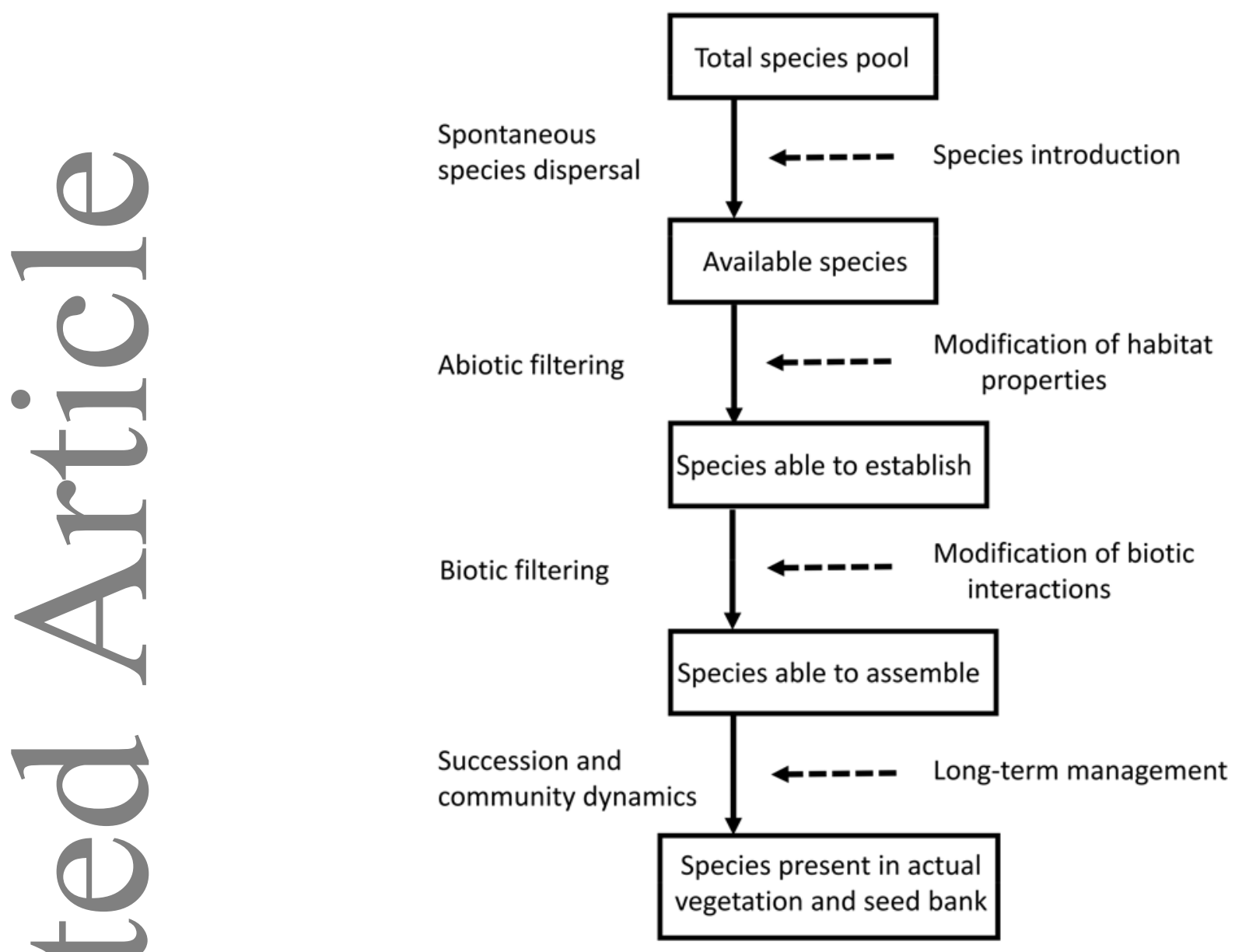

Fig.1: A conceptual framework linking the ecological processes filtering the species pool and ways how active habitat restoration can modify community assembly. 


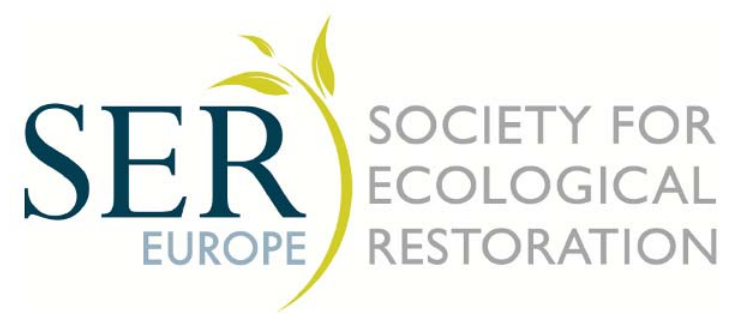

SER Europe is an official chapter of SER International and an international non-profit organization for ecological restoration. The mission of SER Europe is to promote ecological restoration essential for sustainable recovery of the natural biodiversity in Europe and to facilitate the reestablishment of an ecologically healthy relationship between nature and human culture. SER Europe commits to (i) facilitate discussion between researchers, practitioners and stakeholders by organizing conferences, workshops and training courses; (ii) support practitioners and stakeholders with evidence-based knowledge reaching a cost-effective restoration; (iii) encourage the development of research and policy networks over the continent and beyond. (iv) contribute the sustainment and scientific mission of the journal Restoration Ecology; (v) provide scientific background and support for restoration activities; and (vi) provide decision support and contribute to public policy discussions in the field of environmental restoration.

Box 1. SER Europe 